\title{
Initial Academic Literacies/EAP/Genre Practices: Towards Horizontal and Participatory Online-Offline Learning in a Changing World
}

\author{
Nara Hiroko Takaki \\ Language Course, Federal University of Mato Grosso do Sul, Aquidauana, Brazil \\ Email: bobnation@terra.com.br, nara.takaki@ufms.br \\ Received 15 August 2014; revised 30 September 2014; accepted 15 October 2014 \\ Copyright (C) 2014 by author and Scientific Research Publishing Inc. \\ This work is licensed under the Creative Commons Attribution International License (CC BY). \\ http://creativecommons.org/licenses/by/4.0/

(c) (i) Open Access

\begin{abstract}
This article argues in favor of extended possibilities for under-graduate students' initial development of academic literacies/EAP/genre practices. The description of a particular learner's initiative and its consequences constitutes the focus of the paper, which is the result of a research project in a specific context of higher education in Brazil. Qualitative and interpretive aspects characterize the methodology adopted for this investigation for the researcher and the participants' perspectives are considered. It also assumes academic literacy/EAP/genre as situated social practices. The learning theories support the use of Facebook in English language instruction. Portability and multitasking, opportunity to structure learning on personal time and schedule, space for critical authorship and multimodal tasks in collaborative fashion suggest the inseparability between non-dominant forma of literacies and conventional academic literacy/EAP/genre studies.
\end{abstract}

\section{Keywords}

Academic Literacies/EAP/Genre, Meaning Making, Horizontal Participation, Transformative Process

\section{Introduction}

In their article The best of both worlds? Towards an EAP/Academic literacies writing pedagogy, Tribble and Wingate [1] summarize the idea that text and context are indeed the best of both approaches: 
Thus, Johns and Swales (2002) discuss difficulties experienced by undergraduate students and writers of doctoral dissertations. The authors refer to Lea and Street's (1999) concern that students are not supported in understanding the epistemological frameworks of their discipline and propose pedagogical solutions such as critiquing existing guidelines, making features of academic writing more explicit and raising students' awareness of the fact that knowledge is contestable. Similarly, critical EAP scholars, such as Benesch $(2009,2001)$ and Canagarajah (2002), stress the needs for attention to the sociopolitical contexts of writing, the exploration of students' and teachers' social identities and the impact of power relations. Instructional approaches in the Critical EAP tradition include the critical questioning of contextual factors such as power relations and inequalities (Morgan, 2009), and awareness raising of "competing subject positions in conflicting discourse communities" (Canagarajah 2004, p. 117). The exploration of and reflection on contextual features are also seen as fundamental by researchers who use systemic functional linguistics (Halliday, 1994) as their theoretical framework (for instance Motta-Roth, 2009). Their teaching approach tries to enable novice writers to analyse how social roles and practices are constructed in texts.

This quote suggests that while there are theoretical and epistemological points of difference within the two perspectives, and the concern of the social and contextual issues is in common. If this is accepted, meaning makers across a wider range of disciplines at higher education, native and non-native speakers of English alike, might capitalize on their potential and resources that they bring to the academy [2] and, thus, gaining a broader understanding of communication as social practices embedded in political local forces as stated by Canagarajah, [3] and transnational ones, according to Brydon [4].

If the text, the writer's context and the reader's context form the basis for analysis and interpretation in globalized society, then another factor might be brought to the fore: it has been observed how learners themselves create conditions under which they take initiative (as a form of agency) to produce complex and multimodal knowledge and influence others' agency through the digital space [5] [6].

It is the aim of this paper, therefore, to briefly account for the two perspectives, that is, the academic literacy project and the genre practices, and suggest how blended learning [7] on Facebook can foster fluency in writing towards Academic literacies/EAP/genre practices in critical and creative ways as required by the complex, dynamic, knowledge society of present times.

Rather than aspiring to elaborate on a new approach based on certainties and rationalism, this work reiterates the need to create possibilities considering the social place from which participative and transformative pedagogical strategies and practices stem. In this particular study, these strategies are developed through the utilization of multimodal resources (digital, gestural, sound, visual, spatial, to name a few). Each of these modalities is engaged in questions of identity reconstruction and meaning making that have been unmet by conventional modes such as printing.

Before entering the universe towards preliminary practices and thus, preparation for concrete types of genre in digital resources, a brief outline of the main claims of Academic literacies/EAP/genre practices merits space to reinforce the notion that they can all expand views and practices in the enhancement of language curricula and learner autonomy through dialogues among teacher, educator, student, and institution rather than impositions. This work is based on the premise that critical researchers consider technologies as never neutral or disembodied from vested political interests.

\section{Academic Literacy/EAP/Genre: What Seems to Be at Stake Now?}

Positioning from the institutional context in the UK alongside critical ethnographic research on situated text production and practice integrated with a larger social context, Street [7] assumes academic literacies as social practices, that is, as sites where questions of epistemologies and identities flourish rather than mere skills, competences and communication/socialization. This perspective is closely allied to the recent literacies studies [6] [8]-[11], which assume writing, genres and disciplines as discourses intertwined with contested institutional power relations.

From this perspective, writing does matter because the different choices around what and how one write and produces meanings result in different knowledge [12] [13]. In the case of genres, changing meanings and representations from one mode (speech) into another mode (writing) involves a different mix of both modes (layout, semiosis).

Following Tribble, Wingate's reasoning [1], the ideological model proposed by Street [7] [10] [11] empha- 
sizes the transformative nature of academic literacies moving away from the normative attitude, which for this author has prevailed in traditional EAP. For him, traditional EAP identifies academic conventions and explores how students should become proficient or experts following models of discourse and rhetorical structures and genres, eliminating the resources that the students bring to the academy [2].

Street [7] concludes that there are hidden features of academic paper writing which is generated by a criterion based on formulaic lists of things to be covered, usually in terms of structure of the essay (introduction, theory, methods, data), correct academic writing. Such criterion, according to the cited author, could be intimidating for students coming from a large range of disciplines within the broader umbrella of education (history, linguistics, etc.) who would not feel comfortable enough to share their own work, provide their peers with constructive feedback, engage in collaborative work towards transformative attitude and the development of academic literacies.

Reinforcing this view, Leki [14] and Braine [15] understand that academic literacy goes beyond just knowledge of discrete language skills or appropriate language use in context. It needs to be understood holistically and includes, for example, competence in reading, writing, critical thinking, knowledge of independent learning processes, tolerance of ambiguity, effective practice of good judgment, and development of a deeper sense of personal identity.

On the other hand, Tribble, Wingate [1] emphasize that much of the work done by EAP/genre deserves more attention by the academic literacies theorists. They cite genre-based literacy pedagogy used in Australian universities which encourages students to deconstruct texts, join reconstruction and independent construction to acquire knowledge and understanding of the target genre and how to apply that in producing their own individual text. In addition, they mention a new direction of EAP instruction that has redefined the roles of teachers and students [16]-[18]. Despite the lack of clarity regarding the term genre even among EAP practitioners as pointed out by Tribble, Wingate [1], a seminal definition of genre by Swales [19] continues to be the one such authors adopt, that is:

A genre comprises a class of communicative events, the members of which share some set of communicative purpose. These purposes are recognized by the expert members of the parent discourse community and thereby constitute the rationale of the genre. This rationale shapes the schematic structure of the genre and influences and constrains choice of content and style. Communicative purpose is both a privileged criterion and one that operates to keep the scope of a genre as here conceived narrowly focuses on comparable rhetorical action.

They proceed by stating that Swales [19] [20] himself and Bhatia [21] have recognized limitations to this definition, although it has greatly influenced academic writing programs for speakers of diverse languages. Also, Wingate, Tribble [1] presents data from corpus tools, whose analysis suggests that the main focus of EAP/genre researches and pedagogy have been on texts:

As long higher education assessment regimes retain the written text as the main assessment mechanism, it is likely that the production of texts in unfamiliar genres constitute the first and foremost problem of the majority of students; therefore for them the type or text they will have to produce is a good starting point for instructions.

From this quote, the potential of a pedagogical intervention to address the challenges posed by economy society [22] and academic regimes has not received much attention, as academic literacies/EAP/genre have always been invaluable sources of learning [23], unlearning and relearning to be able to renegotiate meanings through writing while reclaiming the local [3] [24].

\section{Revitalizing the Notion of Learning Space}

Due to the intense renegotiation of meanings in contemporary English teaching and learning in non-Englishspeaking countries, literacies have become more transnational. One of the touchstones of transnational literacies is meaningful dialogues to renegotiate knowledge in cross cultural contexts [4] and also through participation through digital tools and web repositories.

A key point is that learning has become more powerfully participatory with complex thinking outside of school. Building on lived experience and getting engaged in learning spaces such as Facebook, Twitter, wikis, blogs, learners are taking control of their lives and influencing others by positioning themselves as text produc- 
ers and text analyzers, in accordance with Gee [25], Hoeshsmann, Stuart [5], Kalantzis, Cope [6], Lankshear, Knobel [8], Monte Mór [26], Morgan [27], just to name a few. This, in turn has changed the configuration of agency, which in the past, took a vertical model, from teacher to student, instead of a horizontal one, where student-student collaborate and co-construct knowledge to be shared, questioned, complemented, recreated, reapropriated and applied in new contexts.

Using literacies to engage in active citizenship means being an adept meaning-maker in the new media that is, being capable of redesigning meanings which are intrinsically multimodal for they combine visual, written, spatial, tactile, gestural, audio and oral modes [5] [6] [28]. Not only that, but also, being able to evaluate information, knowledge across different socio-cultural contexts and perceive the consequences of each form of making meanings for themselves. Such a complex process transforms the meaning maker and other types of meaning making while he/she navigates through different land-digital-scapes.

Teachers, now, can/should create learning experiences through which learners expand their repertoires, develop knowledge and strategies for unlearning and learning, making the familiar unfamiliar. This openness is clearly requested by twenty first century social practices to participate more actively in communities and renegotiate meaning within diversity in economy/knowledge society. How to deal with novelties when they cross into new contexts such as the digital spaces? Such is the responsibility to experimenting with the continuous process of re-shaping meanings, which has come to be known as re-designed. Kalantzis, Cope [6] clarify what this notion entails:

But even if no-one is ever touched by a person's meaning, if no-one hears or sees their message-prompt, it will still have left the representer transformed: it will have helped them to think things through afresh or to see things in a new way. Communication may occur immediately or at some later point if and when a person encounters the message-prompt. This is because the redesigned has joined the repertoire of available designs, so providing openings for new designs. The redesigned—something heard, pictured, written-is returned to the world, and this return leaves a legacy of transformation. Indeed, for having been through this process of transformation, neither the designer nor their world will ever be quite the same again.

In accordance with these authors, one's redesign is the other's resource, which, in turn, may provoke changes in the designer, who becomes a designer redesigned. This can be exemplified when one interprets and reinterprets meanings for different purposes to be further transformed by particular interests for the other interpreters.

The same happens with critical discursive genres [1] [12] [19] [20] [29]. Here, discourse is seen from a sociohistorical perspective as, hence, an intersubjective phenomenon [30] situated within a specific context. While dealing with a specific genre, learners are invited to think about elements such as: the social purpose, the audience to be reached, the linguistic composition, structures, different levels of formality, style, structures, lexical repertoire, phonological and phonetics features (all of them understood as textuality or organization) added by discursive aspects (interaction), choice of multimodal language (gestures, images, sounds, animations) and considerations related to the possible effects on bilingual and multilingual audience.

Such awareness of what to say, how to say it and where to say it, to whom one speaks, writes, or conveys meanings in multiple ways using different media has become crucial for the development of under-graduate students mainly when resources and opportunities seem to be scarce due to historical, social, cultural, economic and political characteristics. This is the context from which a pedagogical alternative is presented and dealt with in the following section.

\section{Critical Engagement in an Under-Graduate Language Public Course in Brazil: Towards Academic Literacies/EAP/Genre Practices}

While I project an image to initiate the discussion on some conceptions such as contingency, uncertainty and possibility, which seem to prevail in twenty first identity, meaning making, teaching, learning, methodology, research, society, human agency, planet, learners seem to have compelling reasons to focus on multimodal shift as they go backwards and forwards among talking about a future conference, taking notes (about the titles and authors of the books I bring into classroom and which are, now, being circulated), miming while greeting a latecomer, formulating ideas of and reading the image projected, touching the screen of their mobile phones, changing from one desk to another to be able to see the image better, all this shows that their physical location influences their perspective from which image reading is to be co-constructed. This is the spirit and engagement with which learners start building a lesson through blended learning environment, which combines the physical 
and the online to promote academic literacies/EAP/genre practice, respecting the learners' linguistic and sociocultural context from which he/she addresses the readers, in a regular language course at University (this is explained on later pages).

Those who have access to a mobile phone (the minority of them with access to Internet, which indicates that it is a priority to improve mobile, computer access and to make broadband more affordable to learners under similar conditions) prove to be expert in searching for information, images, and other productions to complement the material of the lesson. This already shows how significant learners' initiative, engagement and micro-agency in action are.

Mobile communication is a global phenomenon [31] [32]. The use of mobile phones has been recognized as a powerful mode of multimodal pedagogy promoting learning from one mode then to another. In the case of this group (I reserve its contextualization for a subsequent section), learners create meanings about meanings (metarepresentation), reading and posting message and sources of knowledge on Facebook characterizing literacies in the plural. Learners do not have to be at their houses or frequent Lan Houses, to access Facebook to share what happened in the class. They do so while practicing literacies/EAP/genre "live" in collective and collaborative ways. One can even say that they are now interfering and intervening in the professor's choice of material, themes and resources, challenging his/her epistemological and methodological orientations, a contingent and important form of agency in classroom.

I have been witnessing literacies practice intertwined with other literacies practice simultaneously (the former refer to the actual happening in class, whereas the latter represents each time the learners access Google, Facebook, WhatsApp, etc. to interact with others who are not necessarily in the classroom). This means a change in hierarchy as learners build a horizontal scale of relations and scaffolding: they orchestrate the professors' performance of tasks, conceptualization of activities, explanation of conceptions; they assist their peers' learning processes by complementing with information, details of a particular issue being discussed at a particular moment in class; they search for images to illustrate specific points and share them by having their mobile phones circulated in the classroom.

More interestingly, they do not have to wait for the director's or government to provide the institution with technical resources, such as ICT laboratory or other media related equipment. In other words, they enhance their existence, contribute to the others (including mine) life-long learning and agency; they bring the outside world into the classroom and virtual space and real space become practically one, an essential aspect in transnational media literacies.

Such learners grow in an environment in which they make use of conceptual meanings of their narratives, identities, cultures, social practices and of the others from various ever-present and always-needed sources, at least in this community of social practices. The new configuration requires them to fill meanings in a multiplicity of modes, monitor their own thinking self-questioning ways of creating meanings and "being in language" in relation to the others' meanings and other ways of "being in language". Full capacity to interpret and analyse texts and discourses by interrogating the interests of the participants in the process with a view to expanding their own linguistic, cultural, historical repertoires (Portuguese, Spanish, English languages; inter-trans-culturalities; inter-trans-disciplines) using a broader range of pedagogical resources and possible multiple knowledge processes interconnected with local, regional, national, transnational, virtual-real, individual-collective, privatepublic issues and spaces.

While navigating the Net, they experience the known and the unfamiliar and exploit the affordances of the Facebook to make new meanings and apply creatively and critically what they have learned in new contexts, in a single lesson. They are immersed in pluralized literacies and are exposed to possibilities to redesign the direction of the lesson, its content and methodology. Therefore, such redesign influences the knowledge outputs as they become authors/producers of innovative theories-practices. Theories help them understand their social practices and these, in turn, inform them in relation to what, how their theories can/should be transformed to adjust to new contexts and contingent demands.

\section{After All, What Context Is This?}

The project described here is part of a broader ongoing project ${ }^{1}$. This local Project, New literacies, multiliteracies

\footnotetext{
${ }^{1}$ National Project of teacher education, critical education, new literacies, multiliteracies developed by diverse Brazilian universities with a partnership including The University of Manitoba (Dr. Diana Brydon) and Glendon College (York University, with Dr. Ian Martin and Dr. Brian Morgan), under the coordination of Dr. Lynn Mario Trindade Menezes de Souza and Dr. Walkyria Monte Mór, both from USP).
} 
in the teaching of English in Letras: resignifying in global times, assumes the qualitative and interpretive nature of methodology, which means that all the participants' views, attitude, initiative, as well as the researcher's perspectives and theoretical background are included. In addition, contingencies and the possibility to count on exploratory approaches [33] are also relevant. So far data collection has been based on what the learners have produced online.

In this context of research the language course takes place at one of the eleven campuses of the Federal University of Mato Grosso do Sul (in the extreme West of Brazil), located in Aquidauana, a small, historical town with nearly 50 thousand inhabitants. It lasts four years and permits students to choose to hold a teaching certificate either in Portuguese/English languages or Portuguese/Spanish languages or Portuguese/literatures of Portuguese languages.

The vast majority of the students come from public elementary/secondary and high schools, which means too much work is expected from the professors and from the students alike to compensate for: 1) insufficient proficiency for higher education level in the foreign languages, sometimes even in their mother tongue, Portuguese; 2) lack of awareness of what powerful people can do to others when they are users of a powerful tool like the English language; 3) insufficient practices involving academic literacy/EAP/genre, to name a few issues.

A considerable number of such learners are granted two monthly scholarships (in Portuguese, Bolsa permanência and Bolsa alimentação) from the Federal Government. The former is meant to prevent learners from dropping out and abandoning their studies, whereas the latter is intended to assist them in terms of food provision. In return, they are supposed to work for twelve hours a week, participating in projects coordinated by a tutor/ professor. Few of them are in the process of doing research (Scientific Initiation) either as scholarship holders receiving the grant from a Brazilian Research Funding Agency or as volunteers. The great majority of them are family breadwinners or young learners who work during the day and go to university at night, which means they make the most of themselves in class.

Although such students are offered free English and Spanish on campus, that is, free courses run/taught by colleagues and more capable peers, including lessons on Saturdays, a considerable number of students work during the day, frequent university at night and on weekends prefer to dedicate their time to their families. My colleagues and I have been discussing what and how we can do together to change this apparent crystalized situation. I have promoted participatory workshops by selecting recent theories related to critical literacies, new literacies and multiliteracies [5] [8] [9]; and official documents launched by the Brazilian Ministry of Education, the OCEM-LE ${ }^{2}$ [34] with teachers of English from public schools, stuff from the local Municipal Secretariat of Education, under-graduate students and other colleagues from different institutions.

In spite of our efforts, what has been emerging in terms of results is how I make use of the little time dedicated to the English lessons in the graduate course, which is limited to three to five hours per week, each term, during the whole course. The objective of the disciplines ranging from English Language I (first term) to English language VIII (last term) is to develop multiple capacities other than the four skill (listening, speaking, reading and writing) in order to prepare the students to renegotiate meanings in varied contexts permeated by unequal relations of power and knowledge.

The collaborative nature of the course is a challenge and strength in the sense that students have become more aware of what is expected from them in contemporary globalized and digital society. In other words, multiple capacities to take initiative, to produce and share knowledge in different media, to perform in local-regionaltransnational situations in life, to renegotiate meanings in diverse cross-cultural contexts usually within unequal power distribution and collaboratively redefine their roles and actions for the benefit of society. Such learners come from diverse background, from the interior of the State, from rural and urban areas, from the frontiers between Mato Grosso do Sul, Bolivia and Paraguay. Indigenous communities, migrants from the other Brazilian States provide the readers with an idea of the heterogeneity and complexity with which professors, coordinators, directors, students and community members have to grapple with to enhance learning from/with one another without erasing such heterogeneity.

The current state of affairs in my own context of teaching may be considered virtually the same (in terms of proficiency or sufficiency in the English language) as in the other Brazilian contexts, since researchers from more than twenty universities in the four corners of Brazil have been publishing, in accordance with the outcomes of their local research (according to data from publications of situated researches from the previously cited National Project). To move on from this situation, the disciplines I have been teaching with this particular

${ }^{2}$ OCEM-LE refers to Curriculum Guidelines for the teaching of English at High School, 2009. 
group, that is from English V to English VIII, are redesigned to meet the students' needs and interests with various levels of familiarity and facility towards the English language as a means towards meaning makers in today's society.

Consequently, part of my work includes discussions about how different people use language, with what concept of language and their implications in active, responsible, multiple, citizenry and what expectations students bring to writing and meaning making in general, feedback and instructions so that learners can reedit their pieces of writing. I also create space for peer's feedback with productive responses to one another. Some examples comprise pieces of writing and discussions of a particular issue towards intertextuality and more transnational dialogues [4] on Facebook and transfer of writing skills to these medium and other contexts.

It should be noticed that grammar is extremely important. Nevertheless, grammar approaches in such disciplines are contextualized according to the discursive genre to be worked on, whose focus is primarily on how to write, for example, a short personal or opinion essay. I reiterate that this is an exercise to introduce learners to academic genres. Also essential, then, is to develop paragraph unit and/or how to convey meanings via multimodal medium, which involves asking strategic questions/questionings. Morgan [27] is the one who elaborates on this strategy: "Good questions, in this respect, can inspire new meanings and new ways of acting on the content of learning, which ultimately affects and potentially transforms the broader society in whose service learning is ostensibly directed."

In this respect, critical consciencization [35] and critical literacy approaches [36] have a great deal to contribute with pedagogical strategic questions as students read and produce texts. Some of these questions include:

How are the meanings assigned to a certain figure or events in a text?

How does it attempt to get readers to accept its constructs?

What is the purpose of the text?

Whose interests are served by the dissemination of this text? Whose interests are not served?

What view of the world is put forth by the ideas in this text? What views are not?

What are other possible constructions of the world?

In addition to this, engaging with the work of others in respectful ways, citing the others, writing powerful positioning [37], reflecting on their consequences in relation to other powerful positioning in more local-global, transnational ways, definitely constitute complementary means. Whenever necessary, I focus on sentence-level aspects of writing, including concision, cohesion and coherence, discourse management, fundamental features of current EAP [38].

\section{Facebook Page: Bridging the Gap between Learners' Experience and the English Classroom}

On a Facebook page, entitled Twenty-first century meaning makers, designed specifically by an under-graduate student for under-graduate students and, therefore, already confronting issues of power and regulation of meaning that arise from his provocations, Avril (to guard his own identity ${ }^{3}$ ) has become particularly interested in developing English through bridging the gap between a Facebook page and the classroom as focus of investigation of his TCC ${ }^{4}$. He has created this page for the whole class to join in to develop academic literacies/EAP/genre practices as his-our ultimate goal. Nonetheless, Avril believes that he together with his peers might acquire writing skills starting from what he and they already bring as knowledge, experience, abilities and strategies in small scales to renegotiate meanings and from there, embark on a collaborative project towards more elaborated and formal ways to express comments, views, arguments, positioning as ways of exercising agency through specific academic, discursive genres, as our ultimate goals.

Playing the role of a social actor, Avril's initiative resonates the concept of agency by Duff [39] "as people ability to make choices, take control, self-regulate, and thereby pursue their goals as individuals leading potentially to personal or social transformation.” Many times, however, no specific genre is constructed as the vast majority of the learners have great difficulty in producing meanings in intelligible English (in the broadest sense of the word) due to the hypotheses already specified on previous pages. At the same time, learners reported orally, in one of the classes, that they enjoy publishing comments using language or interlanguage in the concept

\footnotetext{
${ }^{3}$ All the names used here refer to nicknames. Avril created this page when he was attending the discipline English language V. The author preserved the learners' original versions, what means no correction was made in terms of grammar.

${ }^{4}$ TCC means Trabalho de Conclusão de Curso. A rough translation would be End-of-Course Monograph. In his TCC, Avril investigated his peers meaning making in the light of recent theories of literacies, under my supervision.
} 
of Tarone [40], that is, as a dynamic process in flexible, but responsible and creative ways or languaging [41] as a tool to articulate thinking, to verbalize and mediate activity/solution to complex problems, and also languaging as a means of historical and political expressions instead of silencing voices [42]. They report having been more worried about their own images and have been learning the hard way to pay attention to their writing style as they are watched by both professor and more capable/proficient peers.

Hoping to have situated the process of preliminary academic literacy/EAP/genre practice of this group of learners I shall now exemplify this transfer of collaboration in literacy/EAP/genre initial practice of a particular context to another context in innovative and transformative ways, and also to show how group identity is constructed, it might be useful to look at the way Avril shared important strategic questions ${ }^{5}$ (he had been exposed to through his readings about literacies to develop his final essay, TCC) to promote discussions among his peers:

Hello friends. The following questions are very relevant for all of us. I would be grateful if you answer them. Good week for all of you.

a) How did you learn to practice critique and connect ideas with your local reality and with the others'?

b) You know that your general formation is not only for languages... technology is not enough, but accelerates... So, how do technologies contribute to your development? Give examples from university, from work and other places.

c) What have you changed in relation to the way you think, act in relation to planning lessons, teaching practice at internship, attitude in relation to each other and diversity?

d) What does a teacher need to know in addition to languages and technology itself?

e) What did you learn outside the classroom and learn here on this page? Do you believe in distant learning?

f) Will we need schools (in the future?)

g) How did you start university and how are you finishing it? Why? Give examples.

Peer A: I started college thinking it was the same school, but with the course I realized that we have a critical sense and be dynamic, not that sameness of the traditional classes, but most classes where students can participate by expressing their views and opinion, regarding the subject matter in question and also activities that have to do with the reality of the student and their community. I learned that despite the distance, we can learn a lot, have knowledge of and interaction, because the Internet is an awesome tool for learning.

As a form of public pedagogy, the subsequent diagram (Figure 1) was posted in order to promote situated language awareness by connecting with his audience in community engagement, highlighting the components he felt to be necessary for the learning process:

Avril: These differences among verbal tenses are very important. But we have to contextualize the grammar. We need to contextualize it in real situations of use. We also need teaching through different kinds of texts and offer possibilities to students to make meaning in a critical way, perspective. Theories about New literacies, Multiliteracies and post-colonial concerns, theories help too much.

\section{Avril: https://www.youtube.com/watch?v=invBjPmY8iE — Simpsons in Brazil ${ }^{6}$}

Peer B: The Brazil despite all the violence that is happening is a beautiful country and wonderful, the vision of this video is wrong, most of the video only mostrou slums, wildlife, naked women, and children stealing demonstrated only downside of our country.

Peer C: In this video it is clear what foreigners think of Brazil, the country of football, where everyone knows playing ball, naked women, on television, wild critters walking around the city, and dangerous and violent slums, where the bad guys take the opportunity to rob tourists, only points negative, which are usually presented in the news of the country.

Peer D: This episode shows how it is sold to the Brazilian reality to Americans. This is all a cultural issue, and we cannot deny that many things shown in the video are real, so clear, some exaggerated, some not.

Avril: People, I read in a newspaper called Mail Online, informations about violence and drugs in Salvador's

\footnotetext{
${ }^{5}$ All the materials, images, links, discussions come from: https://www.facebook.com/groups/291795480954791/

${ }^{6}$ This is part of the thirteenth season of the Simpsons (1001-2002) written by Bob Bendetson and directed by Steven Dean Moore. It was criticized as it includes clichés and stereotypes about Brazil.
} 


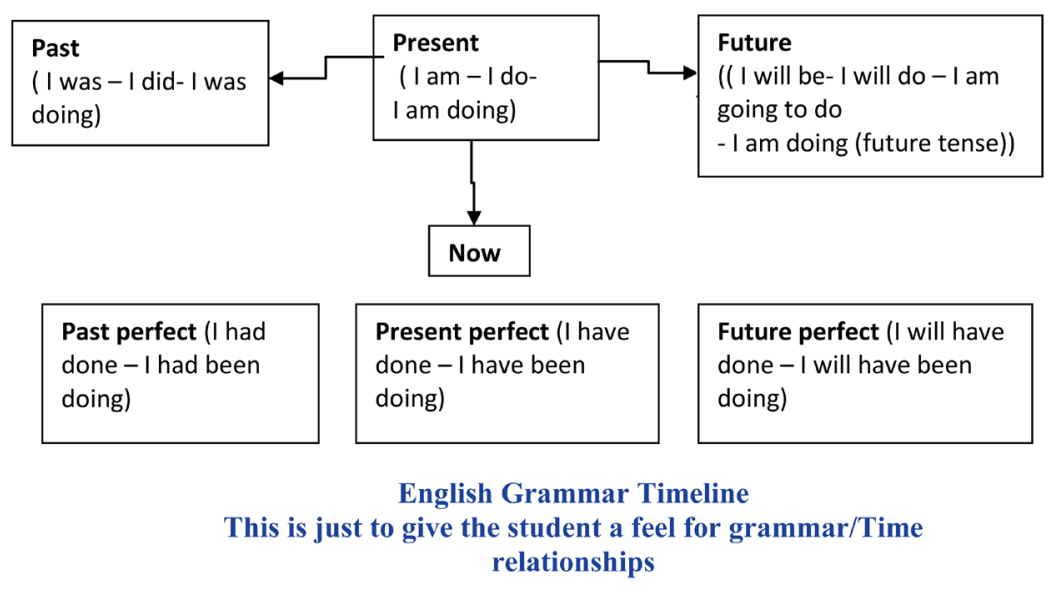

Figure 1. Avril published this diagram to show his peers the importance of contextualizing grammar teaching instead of only presenting rules as shown in the above figure. This was published at: https://www.facebook.com/myenglishteachers.

slums. The text is named "Children who carry guns through Salvador's slums: Shocking images that show drug gangs' brutal grip on Brazil streets where hundreds of thousands will travel for next year's World Cup". Please, read and discuss it. What do you think about?

Peer B: Unfortunately, this is the reality of Brazil, in many capitals that will host the World Cup next year. Drugs and violence predominated in this place, but there are only bandits who live in the slums, but also humble people who for lack of choice and money are forced to live with the violence that dominates the slums. Many slum children are delighted with the ease of earning money and power, starting soon during childhood life in trafficking, and drugs. The lack of investment by the government in education, health, infrastructure, safety and jobs is the one responsible for auto index adults and children in the world of drugs and violence. That is why the population is outraged at the huge expenses of the World Cup, a huge hand stadiums that cost fortunes, of slums and other needy communities in need and suffer from a lack of investment in sectors that are essential for life of the population.

\section{Avril: One more video ${ }^{7}$. http://www.youtube.com/watch?v=PJ6NnGEiucM\&feature=youtu.be}

Peer D: I really liked the music, it represents the time that the country is living and talks about why the protests on the violence with which the police dealt with protesters, it is very interesting that people leave the comfort of their homes and seek their rights.

Peer E: I looooooved this video. Very, very, cool!! It was very creative and real. I can say that it is the another side of the manifestations, not the media side which shows only the vandals destroying everything. We see people fighting for something that really needs to be changed and now. Wake up Braziiiiiiiiill!

Peer F: Critical reality, true and real. The beginning of the movement was small, but gradually was acquiring large tracts, and at the point of climax, millions of people were in the streets protesting their desire for change on several issues, such as education, health, transport fares unfair, not the PEC 37, Cup Brazil in 2014, etc. We need to scream and show the government that we can, and we want a revolution worthy. In demonstrations this year for example, the people who got the PEC 37, who took the power of the prosecutor to investigate crimes committed by politicians, were rejected. Similarly, President Dilma decreed that one hundred percent of oil royalties will be allocated to education. This is perfect for the beginning of the collapse of dirty politics that rages for our country. But we still need more.

Hi everyone! (Avril)

Watch this video ${ }^{8}$ for a discussion and summary on October 1 st:

\footnotetext{
${ }^{7}$ This production refers to a video clip presenting a song created during the Brazilian protests in 2013.

${ }^{8}$ This video clip is about Sugata Mitra's work, professor of technology at the school of education, communication and language sciences at Newcastle University He is presenting his experiment in India showing that in the absence of supervision or formal teaching, children can teach themselves and each other, if they are motivated by curiosity and peer interest.
} 
http://www.ted.com/talks/sugata_mitra_build_a_school_in_the_cloud.html

Sugata Mitra: Build a School in the Cloud|Video on TED.com

Onstage at TED2013, Sugata Mitra makes his bold TED Prize wish: Help me design the School in the Cloud, a learning lab in India, where children can explore and learn from each other-using resources... TED|POR SUGATA MITRA

Avril: I think one of the most important things to do is to start thinking how we can contribute to build a school in the clouds. How we can enable students learn and teach in a collective and individual way? The students learn alone and teach and learn together. How do we watch it in the classrooms, at society in general? We always have to know that the students are meaning makers.

Peer G: Wow, this man is the best! He embraced a challenge and doesn't give up until he sees what the results are. And most interesting is that he is correct in all that he speaks and does, he shows us that learning the way that we transmit and see is getting increasingly outdated. In a world where calculators, computers of all kinds prevail, we need to equip with new weapons to make learning efficient, and as he said, make it a pleasure and not a threat or obligation.

The author reiterates that it is not the aim of this particular article to analyze and discuss the learners' critique per se as this is planned to be looked at/into more specifically in another article, whose main aim is to present and discuss the learners' critical engagement and its implications in contemporary active citizenship and education.

The author does not mean to establish any categorization as a way to standardize language practice, on the contrary, the procedures and activities that I share from now onwards, constitute interesting starting points for an outline of alternative practices in the light of the combination of conceptions related to academic literacy/EAP/ genre studies. In face of the questions regarding the learners' lack of or little systemic/linguistic knowledge of English (for example, the Portuguese speech-like clausal syntax as they are hypothesizing), further practice has been provided, covering thirty minutes of each of the weekly 150-minute meetings per term. To make language visible with its particular conventions and variations, a course kit aiming at more guided practice of the language that was constitutive of the aforementioned interactions was prepared so that learners could apply them in producing their own individual texts, observing the sociopolitical context from/to which they wrote. In other words, it contained explanations and activities in order for the learners to notice language in diverse contexts where situated semantics (cohesion and coherence mainly) and morphosyntax (how terms such as nouns, verbs, adjective, adverbs, pronouns function in a particular context of use) have been priorities.

Learners are usually novices with different experiences in writing. Some of them apply knowledge related to textual production ability from the Portuguese disciplines, such as textual production taught by my colleagues, in which they are exposed to conceptions and practices of genre. There has also been a need to systematize the pedagogical procedures ${ }^{9}$ to make features of academic writing more explicit for the learners and also for them to notice how they can benefit from language studied as whole texts involving routine, creation and some research done in their university ITC laboratory during the classes. Some guidelines include these powerful examples:

Choose a theme you would like to read about;

Search for a site or blog related to this theme;

Find some exemplars of comments people usually publish there;

What is the purpose in question?

Is there a particular kind of audience?

Observe and notice how and more specific ideas are expressed;

Notice how the writer argues in favor or against a particular issue or is reluctant to take a stance;

Think about the choices or patterns related to vocabulary and structures;

How are the sentences connected? Find examples of linking words. What do they express in this context?

Notice the level of formality (Formal, semi-formal, informal language?);

Does the writer interact with the reader? How?

Can you recognize signs of intertextuality? How?

Is it possible to make use of some words, clauses, in your future writing?

Do you identify yourself with this writer's style, "tone of voice”? Why? Why not?

${ }^{9}$ Drawn on and adapted from Motta-Roth (2009). 
What are the advantages of noting language in an activity like this?

Thus far, learners' feedback on this set of procedures has proved to be constructive. However much they try to catch up with the expected level of academic proficiency or sufficiency in the English language (in its broader sense), assisting them in developing academic identity as writers still requires much more time and adjustments within heterogeneity and contingencies.

This group has been with me for one year and a half and it seems that more importantly has been the development of their awareness of reflexivity about the social context and how they can use it as a scaffolding device to explore texts in ways that are meaningful for them. What is relevant for one week, may not be for another. Therefore, they reconstruct the syllabus by signaling what content, forms, resources are available for them so that I can incorporate further practices to develop language awareness and adequate uses in particular moments. The relationship between text, the author's context (production) and the learners' contexts (reception) help them situate their productions and research (in the case of Avril) in the system of genres within multimodal practices.

Language is presented as a socio-multisemiotic system that constitutes the social practices of specific social groups competing with other social practices of other social groups. The fact that they try to attribute meanings to texts [30] shared online mean that they understand that meanings are not ready in such texts, on the contrary they have to make decisions on what is important for them in certain moments and how they are dealt with the endless sources of information in order for them to transform information into knowledge that makes sense to them. This is of utmost importance, that is, the learners' perception that content is not synonymous with knowledge and that knowledge is not pre-given, pre-established, fixed, but rather reconstructed dynamically.

Learners have been associating their context, that is, the social place from which they departure to produce their pieces of writing or comments, observing the relationship between a particular social practice and a specific text (image, advert, YouTube video clip) and analyzing discourses and the way they position people and also the alternatives to deconstruct such mainstream and dominant culture by creating other representations of reality, considering the inherent power inequality that permeates texts and discourses as historical and political means of expressions as opposed to silencing [42]. Peers A, B, C, D, E and F are those who in the beginning of the process most felt insecure probably because of their insufficient proficiency in the language in question and also as newcomers in the world of EAP, rather than lack of digital literacy. Even though they felt like that, Peer A signals some discursive transformation in his way of thinking due to the contingency promoted by the classes:

I started college thinking it was the same school, but with the course I realized that we have a critical sense and be dynamic, not that sameness of the traditional classes, but most classes where students can participate by expressing their views and opinion, regarding the subject matter in question and also activities that have to do with the reality of the student and their community. I learned that despite the distance, we can learn a lot, have knowledge of and interaction, because the Internet is an awesome tool for learning.

Concerning the media coverage of Brazil, in the episode Simpsons in Brazil, Peers C and D question the stereotypes that arise from the video, while Peer $\mathrm{D}$ acknowledges the fact that Brazil is not immune to some truths shown in the video clip, albeit rather exaggerated.

Within the context of escalated climate of fear and violence and the World Cup environment, Peer B takes a stand through advocating in favor of the humble people who have no choice unless live in slums and through denouncing the government investment in stadiums to the detriment of education, infra-structure, health, safety, jobs and adult and children's involvement in drug trafficking.

Peers D, E and F express their views recognizing the power of change. In order to change the situation, people need to function in society and "leave the comfort of their homes and seek their rights", as Peer D affirms. Also, Peer E brings to discussion positive aspects that the media does not disseminate: the ability to take advantage of the moment and produce a video clip in creative and realistic ways as a form of embodied public/collective manifestation. Peer $\mathrm{F}$ amplifies the discussion by showing how informed he/she is and invigorates the people's reactions against the PC 37 and the President's discourse as two good results.

There has been recognition that technology enhances learning spaces for children to become more autonomous to foster authorship instead of mere readership, in collaborative modes, which challenges the conventional ways of teaching-learning, as both Avril and Peer F declare, while constructing meaning regarding Sugata Mitra's project to build a school in the clouds in India.

More outcomes are expected for the second article I intend to write focusing on learners critique as the continuation of my research process based on the new tasks have been worked on and proposed, such as the produc- 
tion of argumentative essays and a letter to the editor of a local newspaper.

Indeed, from a critical literacy perspective [10] [36], they show evidence that they are in the process of, for example, creating a habit to privilege the personal, the social over the commercial or neoliberal. At the same time, from the perspective of academic literacy/EAP/genre practices, they have some notions of the social purpose of their production, who the audience (peers and the professor, who is also the author of this paper) and the informal, semi-formal style they are supposed to use added by some appropriate structures and lexical items.

As time went by, they got less inhibited to make a move and heated debates were published. This scenario invited me to develop new conceptual orientation and approach: to ask them to refer back to their written productions and try, either individually or in groups to reedit them, this time paying more attention to textuality (organization of content) together with grammatical forms, aspects related to structure, composition, style, lexis, accuracy and discursive features (interaction), according to the state of readiness of each learner.

The object of study in this phase is not language as an end in itself. The validity of this phase was determined by the relevance it has been having to classroom practice and, ultimately to learners' learning processes and outcomes. Two types of collaboration have been identified: one in which the more capable peers help the others by reading their written production and providing them with language input/revision to be taken into account while reediting the original text; the other in which I myself revise linguistic and discursive aspects in class by showing learners the situated cases that deserve attention/reformulation, collected from their texts. In this case, they discuss possible alternatives for improvement of such cases and I write them on the board or screen.

Making clear what help is available and how they can seek for clarification in a supportive learning tutor/ professor together with other face-to-face encounters have certainly contributed to avoid retention problems at this course in this particular context with all the concerns already exposed here.

To sum up, language instruction has been organized in this way, that is, I do not expect instant learning and immediate accuracy. I have practiced teaching that allows for plenty of recycling and exposing learners to language beyond their productive means, so that they have the opportunity to grasp new forms which they are "ready" for.

The new versions will be published on the Facebook page and they will certainly recruit other peers to comment, suggest and share constructive feedback. As the world of academic literacy/EAP/genre practice is rich, never uniform and independent of the learner's socio-historical context, and as it demands time and effort, future work on modality, composition, discourse (interaction) and some other forms of interventions will have to be strategically elaborated for handling it in feasible and optimal ways.

Nevertheless, simply becoming familiar with diverse forms of literacy or with a repertoire of literate practices may not be sufficient to cope with life, work, leisure, community activities, personal growth, social transformation and active citizenship and education. Therefore, understanding the resources of language (as the strategy of constant questioning as already presented here), images, digital rhetorics to reconstruct different kinds of meanings has been provided to these learners through exposure to video clips from YouTube, images and other multimodal materials across disciplines that Avril captured due to his "e-initiative" within this blended learning environment.

These are some of the pedagogical interventions and activity delivery designed to increase learners' participation in written debates. This is an ongoing, collaborative endeavor with the great advantage of crossing divides and it also purports to blend pedagogical procedures of academic literacy/EAP/genre practice through taking learners' livid experience and diverse forms of communication across time, space and culture. In such space, learners constantly define and redefine the writer/author's self, their selves as interconnected with other selves. It amplifies their social capabilities, giving rise to creativity, critique and trans-multimodal work which has no historical parallel and it only became possible also due to Avril's cyber agency ${ }^{10}$ to go through his TCC research embedded in my particular context of teaching-researching., inside and outside the university walls.

It is within this conciliation of academic literacy/EAP/genre preliminary practices together with a combination of physical, virtual environment, intersubjectivity, subjectification [43] that language course at universities can meet new social demands. Subjectification refers to educational arrangements that allow the learners become more autonomous and independent in their thinking and acting/inacting within multiple existing and emerging social orders. Autonomy/agency might be already ingrained in each of these learners everyday life that generates synergies among a range of oral, written, multimodal, social practices.

\footnotetext{
${ }^{10}$ Term coined by this the author of this paper to mean social action taken in digital space in participatory and transformative fashion.
} 
All of these practices indicate that subjectification is also a means to extend their learning outside the school premises. Being computer literate or academic literate or both do not necessarily ensure criticality, that is, being political, social, cultural, economically engaged in different modes of thinking, judging and acting/inacting in confrontation with other modes of thinking, judging, and acting/inacting, which invites educators to revise their roles in school/university curricula worldwide. In other words, intersecting formalized education with the learners' ubiquitous media literacy practices merits further exploration to unfold pedagogical implications of one's ever-changing mediated life.

To highlight part of his transformation throughout the course, Avril has published a personal report as a discursive genre to incentivize his peers to continue participating on the referred Facebook page, practicing reading, watching, listening, writing while developing critique, creativity and autonomy/agency in customized fashion, an essential quality to perform in digital society.

Facebook was a great tool/way to improve my English skills. Last year, for instance, when I created a closed group-21st century meaning makers-to develop my TCC (Course Conclusion Work) research, I intended to investigate and try to understand how academics (my classmates) of the seventh and eighth semesters of the Letters/Language Course made meaning/created knowledge through hypermodalities, mainly, in English; of course, I was one of those participants too. After beginning my research, when my classmates and I started to share some materials-images, memes, cartoons, video clips, News from newspapers and from TV, for example, I realized this digital environment/setting is an excellent tool for those who do not have, at least, good oral English proficiency, because they discussed many important social and educational themes through the digital writing. Besides that, they could improve their listening and readings skills. During the discussions, I was concerned and aware of emphasizing and contemplating theories about multiliteracies, new literacies, critical literacy, i.e. the relationship of these concepts with the field of education, with the English teaching and learning. My classmates read the informations, interpreted them, re-interpreted them, did cultural translation (Menezes de Souza, 2007), making meaning in their cultural and social contexts, for example. And these are good contributions to reflections upon the way we "teach", learn and understand us in relation to the local and global contexts. Studying, teaching, learning through the use of Facebook is better, from my standpoint, than to stay and study among four walls in a classroom, using only pen, pencil, eraser, printed books, notebook to improve writing and aspects of normative grammar. But digital/virtual Technologies are not all we need and it depends on our specific and general aims, because you can use laptops, computers, Smartphones, Messenger, Skype, WhatsApp, any kind of social network and technology and reproduce "the old wine in new bottles" (Lankshear and Knobel, 2003, p. 54) -i.e. to teach Terena, English, Portuguese, Japanese, Spanish, Russian, any language, in "traditional” ways, for instance: to teach only grammar through isolated sentences. We can teach grammar in a useful, pleasant and contextualized way, according to different aims and contexts of use. Still in relation to my TCC, I realized that at times some classmates produced liberal-humanistic critical reading (Cervetti, Pardales and Damico, 2001) and at other times, they made meaning in a critical and contextualized way-critical literacy (Cervetti, Pardales e Damico, 2001, McLaughlin and De Voogd, 2004; Monte Mór, 2013, Street, 1984). So, I believe to teach and learn a mother tongue and/or any second/foreign language, through a closed group on Facebook, for example, is a challenge for those who want to promote reflection, action and identity reconstruction and social transformation (as Paulo Freire teaches us). Transformation in the way we make lesson plans, observe students, interact and act with them in society, develop/improve strategies, abilities, methodologies, digital and social inclusion and (new-multi-hyper) literacies. I consider the reflection, above, very important, because nowadays we have to develop and have multiple capacities. Society requires them. We cannot be good at many things, we must be excellent at a lot of things and each day learn more, otherwise, you/we are going to be left behind. I am trying to learn every day, because "to teach" is, actually, a complicated word in a complex world.

As one can perceive, Avril seems to have grasped what it means to be critical literate while being meaningfully engaged in contemporary spaces, an essential component for active citizenship today. Far from being a free floating agent, he has also fostered leadership and agency through media literacies. He is the one who created this page specifically for provoking other peers' problematization of issues rather than mere exchange of knowledge/ideas/experience and also promoted space for learning from/with the others in collaborative and meaningful ways [33] approximating society, transnational literacies [4] and the production of local meanings [3]. One 
can say that he in tune and largely at ease with the multimediating construction of response to his classroom, with the social cultural shifts brought about by the global times and the development of new technologies. By adopting an active and critical stance, he created the Facebook page to provide his peers with access to more opportunities for literacy/EAP practices in non-threatening environment, in innovative and user-friendly ways.

As regards, for example, the absence of indentation to start the paragraphs, Avril might be aware of such inadequacies in the text he produced. When I asked him why he had made such choices, he argued that transposing models and exemplars from page to screen might distance his peers, for they would feel controlled. A possible interpretation of his saying would be that outsiders/newcomers of digital space do not have the experiences, abilities, and resources to draw on in the same way that insiders do [8]. There are different ways of looking at these concerns depending on whether one comes from the physical space mindset or from the alternative mindset associated with understanding communication and socialization, spatial "laws" online, in situated and historical manner. It seems that he has applied this strategic resource to attract attention and that he knows how to identify where, how data will be useful to him and to his peers, and how to make use of it to serve his/their/our purposes (how to live and negotiate attention and meanings and develop new kinds of relationship/alignments there).

Also, some hints are provided in the sense that Avril may not only know a great deal of academic literacy/ EAP/genre practice, but also how to be sensitive to other peers who might bring different cultural and critical manners of thinking about such practices in a specific medium to produce some kind of 'academic literacy/EAPrelated' outcome.

At the end of the research, he was able to produce a "conversation" in shared space, a piece of writing, which I consider to be an excellent tool for engaging learners in their academic literacy/EAP/genre practice in the plural sense, for the physical environment may be lonely and limited in terms of who can be reached and what can be disseminated, produced and reconstructed. Such a complex process of writing reflects Avril's whole process of learning, teaching, unlearning and reconstructing his identity and narratives and hopefully the other peers will be transformed in the near future and/or in the long run. They are not enrolled in a formal online course. On a voluntary basis, they have realized how they can associate the inter-personal with the online practices towards academic writing/EAP/genre practice in more horizontal fashion.

At the same time, he develops a more intersubjective approach to re-narrate his story from the perspective of a learner in a non-English speaking country. Furthermore, owing to the interconnectivity offered by the Internet, by the social networking (in this case this particular page on Facebook), he was able to bridge the gap between local and more transnational spaces for meaning making and agency to transform his own epistemologies, ways of making sense of the world, ways of reading the word and the world [35] and of his peers' ways of making sense of the world, ways of reading the word and the world. I shall complement this assumption by adding writing the world and the world in responsible and collective ways.

\section{Conclusions}

The partial success of this ongoing process in my research suggests that young learners and adults' academic literacy/EAP/genre practice are developing rapidly as a result of their passion for Facebook. Contrary to many people's judgment, Facebook is not only for sharing news, ideas, links, photos, events, arquives, but mainly for its significant potential in this field of knowledge and research. Clearly, teachers-professors-researchers could benefit by knowing more about the way young learners and adults make use of Facebook.

Pedagogical practices built by epistemological basis like the one described here, unlike mere knowledge repositories, as they are ideological and more "democratic" forms of literacies [11] represent an alternative knowledge network connecting people to people. Paraphrasing [6] such practices operates within diverse voices, accents, media, scripts, in a space where none of these elements has supremacy over the other(s). It enhances learners' engagement in maintaining, transforming their cultural world. As a social event in conjunction with the learner's knowledge, values, critique, creativity, ethics, Avril's social practices will hopefully influence others to narrate their stories and histories, identities while renegotiating meanings in diverse media.

For this paper, I exemplified this experience by addressing mainly one learner's process of developing selfknowledge to understand him better and the other(s) using writing to express, sometimes, a youthful, casual, up to date identity and mainly to improve his writing skills and manage relationship in the group, as a kind of monitor. Many other learners published many comments and are now, starting to publish their own creative writing. 
Concentration has increased. They are not missing out educational opportunities despite the drawbacks concerning affordable broadband Internet access. It seems that little attention has been drawn to academic literacies research involving learners for whom English is a foreign language and, in this sense, this article is preliminary when proficiency in academic literacy/EAP/genre practice depends very much not only on the mastery of linguistic features, but also on ideological, discursive practices of constructing and renegotiating knowledge in digital spaces.

\section{Acknowledgements}

I would like to thank the under-graduate students studying English at the Federal University of Mato Grosso do Sul, from 2010 to 2014, who have supported part of my research which has generated this article. I also thank two anonymous reviewers for this journal for their most relevant comments and suggestions on preliminary versions of this paper. The mistakes that remain are my own.

\section{References}

[1] Tribble, C. and Wingate, U. (2012). The Best of Both? Towards an EAP/Academic Literacies Pedagogy. Studies in Higher Education, 37, 481-495. http://dx.doi.org/10.1080/03075079.2010.525630

[2] Lillis, T.M. and Scott, M. (2007). Defining Academic Literacies Research: Issues of Epistemology, Ideology and Strategy. Journal of Applied Linguistics, 4, 5-32.

[3] Canagarajah, S. (2005) Reclaiming the Local in Language Policy and Practice. Lawrence Erlbaum Associates, Inc., Mahwah.

[4] Brydon, D. (2011) Brazil/Canada Knowledge Exchange: Developing Transnational Literacies. http://dianabrydon.com/2011/03/30/brazilcanada-knowledge-exchange-developing-transnational-literacies/

[5] Hoeshsmann, M. and Stuart, P. (2012) Media Literacies: A Critical Introduction. Wiley-Blackwell Publishing, Malden. http://dx.doi.org/10.1002/9781444344158

[6] Kalantzis, M. and Cope, B. (2012) Literacies. Cambridge University Press, Melbourne. http://dx.doi.org/10.1017/CBO9781139196581

[7] Street, B. (2009) Academic Literacies: Approaches to Genre? 5th International Symposium on Textual Genre Studies (VSIGET), Caxias Do Sul, 11-14 August 2009.

[8] Lankshear, C. and Knobel, M. (2008) New Literacies: Everyday Practices and Classroom Learning. 2nd Edition, Open University Press, New York.

[9] Gee, J.P. (1996) Social Linguistics and Literacies: Ideology in Discourses. Falmer Press, London.

[10] Street, B. (1984) Literacy: Theory and Practice. Cambridge University Press, New York.

[11] Street, B. (2014) Letramentos sociais. Abordagens críticas do letramento, desenvolvimento, na etnografia e na educação. Tradução de Marcos Bagno. Parábola Editorial, São Paulo.

[12] Bazerman, C. (2007) Escrita, gênero e interação social. Dionísio, A.P. and Hoffnagel, J.C., Eds. \& Trans., Cortez, São Paulo.

[13] Bazerman, C. (1988) Shaping Written Knowledge: The Genre and Activity of the Experimental Article in Science. University of Wisconsin Press, Madison.

[14] Leki, I. (2000) Writing, Literacy, and Applied Linguistics. Annual Review of Applied Linguistics, 20, 99-115. http://dx.doi.org/10.1017/S0267190500200068

[15] Braine, G. (2002) Academic Literacy and the Non-Native Speaker Graduate Student. Journal of English for Academic Purposes, 1, 59-68. http://dx.doi.org/10.1016/S1475-1585(02)00006-1

[16] Benesch, S. (2001) Critical English for Academic Purposes. Lawrence Erlbaum Associates, Mahwah.

[17] Benesch, S. (1999) Needs Analysis and Curriculum Development in EAP. TESOL Quarterly, 28, 313-329.

[18] Pennycook, A. (1997) Vulgar Pragmatism, Critical Pragmatism, and EAP. English for Specific Purposes, 16, $253-269$.

[19] Swales, J.M. (1990) Genre Analysis. Cambridge University Press, Cambridge.

[20] Swales, J.M. (2004) Research Genres. Cambridge University Press, Cambridge. http://dx.doi.org/10.1017/CBO9781139524827

[21] Bhatia, V.K. (2004) Worlds of Written Discourse: A Genre-Based View. Continuum, London.

[22] Ferreira, M.M. (2012) O letramento acadêmico em inglês: Dificuldades na confecção da seção introdução de artigos acadêmicos. Revista Brasileira de Linguística Aplicada, 12, 1025-1048. 
http://dx.doi.org/10.1590/S1984-63982012000400017

[23] Gilliver-Brown, K. and Johnson, E.M. (2009) Academic Literacy Development: A Multiple Perspectives Approach to Blended Learning. http://www.ascilite.org.au/conferences/auckland09/procs/gilliver-brown.pdf

[24] Lillis, T. and Curry, M.J. (2010) Academic Writing in a Global Context. Routledge, London.

[25] Gee, J.P. (2004) Situated Language and Learning: A Critique of Traditional Schooling. Routledge, New York.

[26] Monte Mór, W. (2010) Multimodalidades e comunicação: Antigas novas questões no ensino de línguas estrangeiras. Letras \& Letras, 26, 469-478.

[27] Morgan, B. (2009) Fostering Transformative Practitioners for Critical EAP: Possibilities and Challenges. Journal of English for Academic Purposes, 8, 86-99. http://dx.doi.org/10.1016/j.jeap.2008.09.001

[28] Kress, G. (2003) Literacy in the New Media Age. Routledge, London. http://dx.doi.org/10.4324/9780203164754

[29] Motta-Roth, D.M. and Heberle, V.M. (2005) O conceito de "estrutura potencial do gênero" de ruqayia hasan. In: Meurer, J.L., Bonini, A. and Mota-Roth, D. (Orgs.), Gêneros: Teorias, métodos, debates, Parábola Editorial, São Paulo, 12-28.

[30] Bakhtin, M.M. (1986) Speech Genres and Other Late Essays. University of Texas Press, Austin.

[31] Donner, J. and Walton, M. (2013) Your Phone Has Internet—Why Are You at a Library PC? Re-Imagining Public Access for the Mobile Internet Era. In: Kotze, P., et al., Eds., Interact, Part I, LNCS, Springer, 8117, Berlin, 347-364.

[32] Walton, M. and Donner, J. (2011) Read-Write-Erase: Mobile-Mediated Publics in South Africa's 2009 Elections. In: Katz, J.E., Ed., Mobile Communication: Dimensions of Social Policy, Transaction Publishers, New Brunswick, NJ, $117-132$.

[33] Gee, J.P. (2004) What Video Games Have to Teach Us about Learning and Literacy. Palgrave Macmillan, New York.

[34] Brasil (2006) Orientações curriculares para o ensino médio: Linguagens, códigos e suas tecnologias—Conhecimentos de línguas estrangeiras. Ministério da Educação/Secretaria de Educação Básica, Brasília. http://portal.mec.gov.br/seb/arquivos/pdf/book_volume_01_internet.pdf

[35] Freire, P. (2005) Pedagogia da tolerância. Editora da UNESP, São Paulo.

[36] Cervetti, G., Pardales, M.J. and Damico, J.S. (2001) A Tale of Differences: Comparing the Traditions, Perspectives, and Educational Goals of Critical Reading and Critical Literacy. www.readingonline.org/articles/cervetti/

[37] Shor, I. (1992) Empowering Education: Critical Teaching for Social Change. University of Chicago Press, Chicago.

[38] Cummins, J. (2000) Academic Language Learning, Transformative Pedagogy and Information Technology: Towards a Critical Balance. TESOL Quarterly, 34, 537-548. http://dx.doi.org/10.2307/3587742

[39] Duff, P. (2012) Issues of Identity. In: Gass, S. and Mackey, A., Eds., Handbook of Second Language Acquisition, Routledge, London, 410-426.

[40] Tarone, E. (2009) A Sociolinguistic Perspective on Interaction in SLA. In: Mackey, A. and Polio, C., Eds., Multiple Perspectives on Interaction: Second Language Research in Honor of Susan M. Gass, Routledge, New York, 41-56.

[41] Swain, M. (2006) Languaging, Agency and Collaboration in Advanced Second Language Proficiency. In: Byrnes, H., Ed., Advanced Language Learning: The Contribution of Halliday and Vygotsky, Continuum, London, 95-108.

[42] Ramanathan, V. (2009) Silencing and Languaging and the Assembling of the India Nation-State: British Public Citizens the Epistolary Form, and Historiography. Journal of Language, Identity \& Education, 8, 203-219. http://dx.doi.org/10.1080/15348450902848874

[43] Biesta, G.J.J. and Lawy, R.S. (2006) From Teaching Citizenship to Learning Democracy: Overcoming Individualism in Research, Policy and Practice. Cambridge Journal of Education, 36, 63-79. http://dx.doi.org/10.1080/03057640500490981 
Scientific Research Publishing (SCIRP) is one of the largest Open Access journal publishers. It is currently publishing more than 200 open access, online, peer-reviewed journals covering a wide range of academic disciplines. SCIRP serves the worldwide academic communities and contributes to the progress and application of science with its publication.

Other selected journals from SCIRP are listed as below. Submit your manuscript to us via either submit@scirp.org or Online Submission Portal.
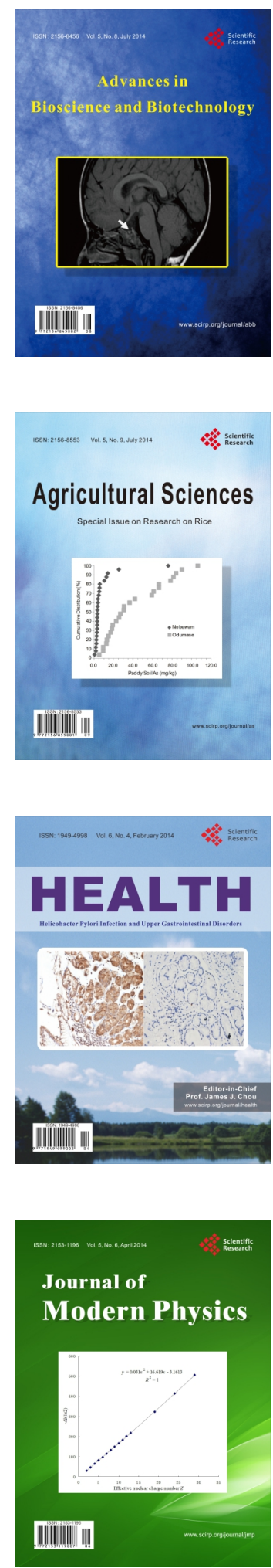
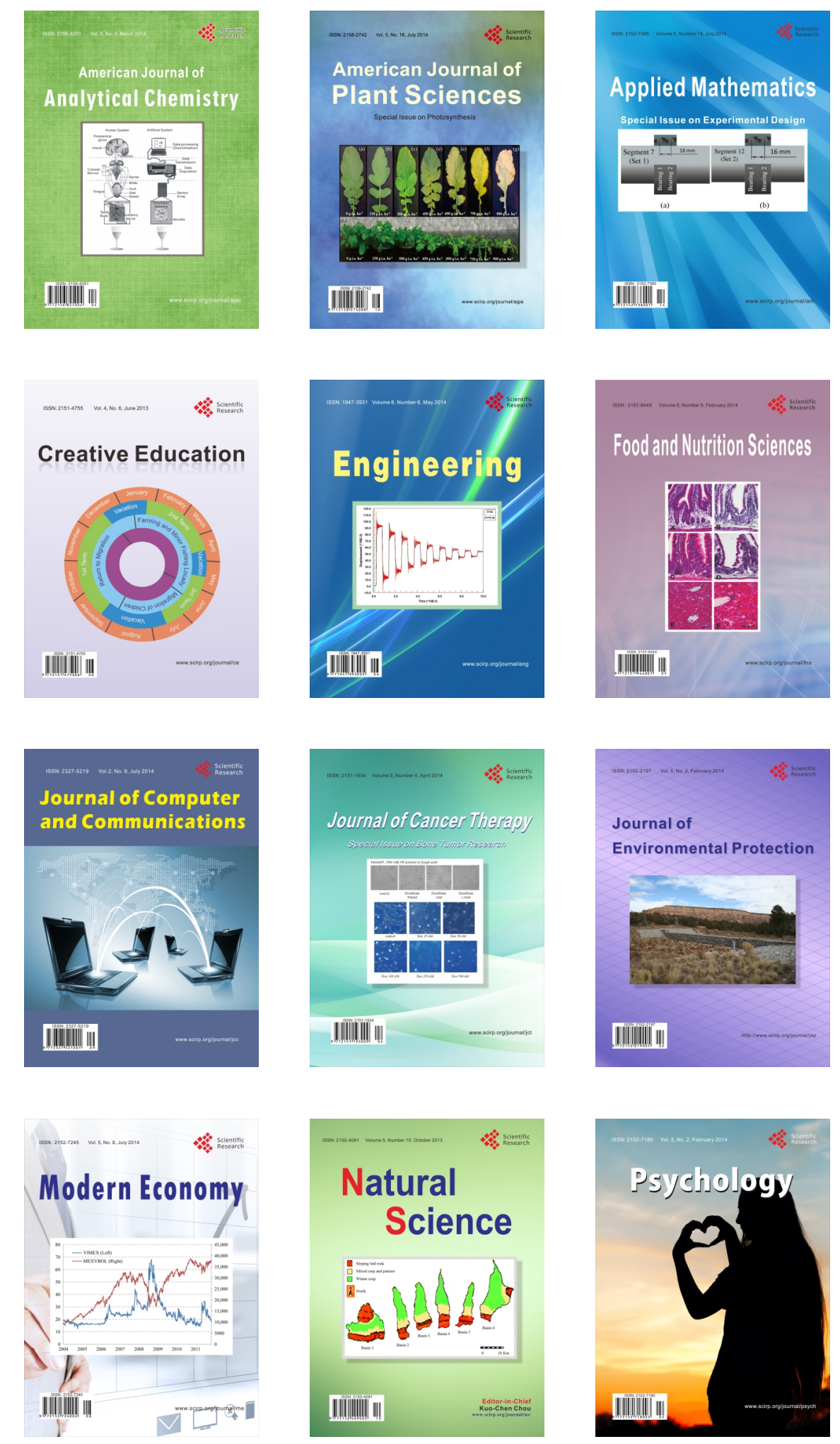